\title{
ADDITIVE ALLOMETRIC MODELS OF SINGLE-TREE BIOMASS OF BETULA SP. AS A BASIS OF REGIONAL TAXATION STANDARDS FOR EURASIA
}

\author{
Vladimir Andreevich USOLTSEV ${ }^{1,2}$, Seyed Omid Reza SHOBAIRI ${ }^{2, *}$, Viktor Petrovich \\ CHASOVSKIKH ${ }^{2}$ \\ ${ }^{1}$ Botanical Garden, Russian Academy of Sciences, Ural Branch 8 Marta str., 202a, Yekaterinburg, \\ 620144 Russian Federation. \\ ${ }^{2}$ Ural State Forest Engineering University Sibirskii trakt, 37, Yekaterinburg, 620100 Russian \\ Federation. \\ * corresponding author: Omidshobeyri214@gmail.com.
}

\begin{abstract}
In recent years, as the ecological role of forests has grown to a global level, the need to analyze their biological productivity in terms of biogeography has increased. Such studies are carried out mainly on a regional scale at the levels of both single-trees and forest stands. Thanks to formed by the authors the database on the biomass of 1076 sample trees of the genus Betula sp. growing on the territory of Eurasia, the trans-Eurasian model of tree biomass is proposed for the first time. The model takes into account regional differences in the biomass structure of equal-sized trees, harmonized on the principle of additivity.
\end{abstract}

\section{Keywords:}

Genus Betula sp.; Equations additivity; Biosphere role of forests; Biomass of trees and forests; Allometric models.

\section{Introduction}

The world is experiencing unprecedented forest ecology-scale information splash in estimates of biological productivity and carbon-depositing capacity of forests in the assumption of anthropogenic climate change and finding capacity of his stabilization. In recent years, the scientific branch associated with the estimating the biological productivity of trees and stands is the most intensely developed in two aspects: (1) in compiling the world's actual data bases on biological productivity at the levels of forest stands and sample trees with their development through global and transcontinental patterns $[7,20,23,26,37]$ and (2) in the development of methodological bases of regression modelling with the aim to improve the accuracy of our estimates and the correctness of the empirical models of biological productivity of forests and their constituent trees, namely, in directions of developing harmonized and mixed-effects models.

The development of generic allometric biomass models $[5,6,22,25,27,29,32,38,42]$ is replaced by the phasing out of them and moving on to the concept of their harmonizing. Harmonization implies at least two directions: (1) designing of compatible regional models based on dummy variables $[13,14,15,16,18,19,31,33,36,37,39,40,41]$ and (2) designing of compatible models based on the principle of additivity of biomass component composition $[2,3,4,9,10,11,12$, $21,28]$.

In this article, the first attempt to develop a harmonized allometric transcontinental model of tree biomass, which combined both mentioned by [17] approaches, namely, ensuring the principle of additivity of component composition and localization (unbundling) of additive biomass model according to regions of Eurasia by introducing dummy variables. In other words, an attempt was made to solve the problem of joining additivity and universality in a single model on the example of birch (genus Betula sp.). The model will serve as a basis for designing the regional trans-Eurasian standards with a view to assessing the biomass of birch trees and stands according to regions of Eurasia. 


\section{Material and methods}

In recent years across all the territory of Eurasia the database on single-tree biomass in a number of 7300 definitions on sample plots was first compiled and published [34, 35]. More than $70 \%$ of the materials fall on the territory of Russia and countries of the former USSR. The genus Betula sp. involves about 120 species from which data on tree biomass are available for 7 of the total species quantity.

Of the mentioned database the materials in a number of 1076 sample trees of four vicarage species of the genus Betula sp. (B. alba L., B. platyphylla Suk., B. costata Trautv. and B. dahurica Pall.) are taken that are distributed in 11 eco-regions and marked respectively by 11 dummy variables from $X_{0}$ to $X_{10}$ (Table 1). The distribution of sample plots, on which sample trees are taken in different ecoregions of Eurasia, is shown in Fig. 1.

Table 1: The scheme of regional coding actual biomass of 1076 birch sample trees by dummy variables.

\begin{tabular}{|c|c|c|c|c|c|c|c|c|c|c|c|c|c|c|}
\hline \multirow{2}{*}{ Region* } & \multirow{2}{*}{$\begin{array}{l}\text { Species of } \\
\text { Betula sp. }\end{array}$} & \multicolumn{10}{|c|}{ Dummy variables } & \multirow{2}{*}{$\begin{array}{c}\text { Range of DBH, } \\
\mathrm{cm}\end{array}$} & \multirow{2}{*}{$\begin{array}{c}\text { Range of } \\
\text { tree height, } \\
\text { m }\end{array}$} & \multirow{2}{*}{$\begin{array}{c}\text { Number of } \\
\text { measure- } \\
\text { ments }\end{array}$} \\
\hline & & $X_{1}$ & $X_{2}$ & $X_{3}$ & $X_{4}$ & $X_{5}$ & $X_{6}$ & $X_{7}$ & $X_{8}$ & $X_{9}$ & $X_{10}$ & & & \\
\hline WME & B. alba L. & 0 & 0 & 0 & 0 & 0 & 0 & 0 & 0 & 0 & 0 & $0.5 \div 21.0$ & $2.1 \div 18.8$ & 12 \\
\hline ER & B. alba L. & 1 & 0 & 0 & 0 & 0 & 0 & 0 & 0 & 0 & 0 & $0.9 \div 41.8$ & $2.2 \div 27.1$ & 160 \\
\hline Ural & B. alba L. & 0 & 1 & 0 & 0 & 0 & 0 & 0 & 0 & 0 & 0 & $1.0 \div 31.0$ & $2.7 \div 26.4$ & 193 \\
\hline WSst & B. alba L. & 0 & 0 & 1 & 0 & 0 & 0 & 0 & 0 & 0 & 0 & $0.5 \div 48.0$ & $1.7 \div 25.0$ & 571 \\
\hline MS & B. alba L. & 0 & 0 & 0 & 1 & 0 & 0 & 0 & 0 & 0 & 0 & $0.2 \div 44.7$ & $1.5 \div 26.6$ & 64 \\
\hline FEn & B. platyphylla S. & 0 & 0 & 0 & 0 & 1 & 0 & 0 & 0 & 0 & 0 & $6.7 \div 27.1$ & $6.6 \div 14.2$ & 5 \\
\hline FEs & B. platyphylla S. & 0 & 0 & 0 & 0 & 0 & 1 & 0 & 0 & 0 & 0 & $9.1 \div 30.5$ & $12.5 \div 26.0$ & 7 \\
\hline FEs & B. costata Tr. & 0 & 0 & 0 & 0 & 0 & 0 & 1 & 0 & 0 & 0 & $8.6 \div 30.2$ & $15.3 \div 20.9$ & 7 \\
\hline FEs & B.dahurica Pall. & 0 & 0 & 0 & 0 & 0 & 0 & 0 & 1 & 0 & 0 & $9.8 \div 30.8$ & $13.7 \div 20.4$ & 7 \\
\hline $\mathrm{Ch}$ & B. platyphylla S. & 0 & 0 & 0 & 0 & 0 & 0 & 0 & 0 & 1 & 0 & $0.2 \div 28.0$ & $1.5 \div 20.0$ & 17 \\
\hline Jap & B. platyphylla S. & 0 & 0 & 0 & 0 & 0 & 0 & 0 & 0 & 0 & 1 & $4.3 \div 16.4$ & $7.2 \div 19.8$ & 33 \\
\hline
\end{tabular}

${ }^{*}$ Region designations: WME - West and Middle Europe; ER - European part of Russia, Central territory; Ural - Middle and Southern Ural; WSst - Western Siberia, steppe; MS - Middle Siberia, Southern taiga; FEn - Far Vostok, Northern taiga; FEs Far East, Primorie; Ch - Northeast China and Mongolia; Jap - Japanese islands.

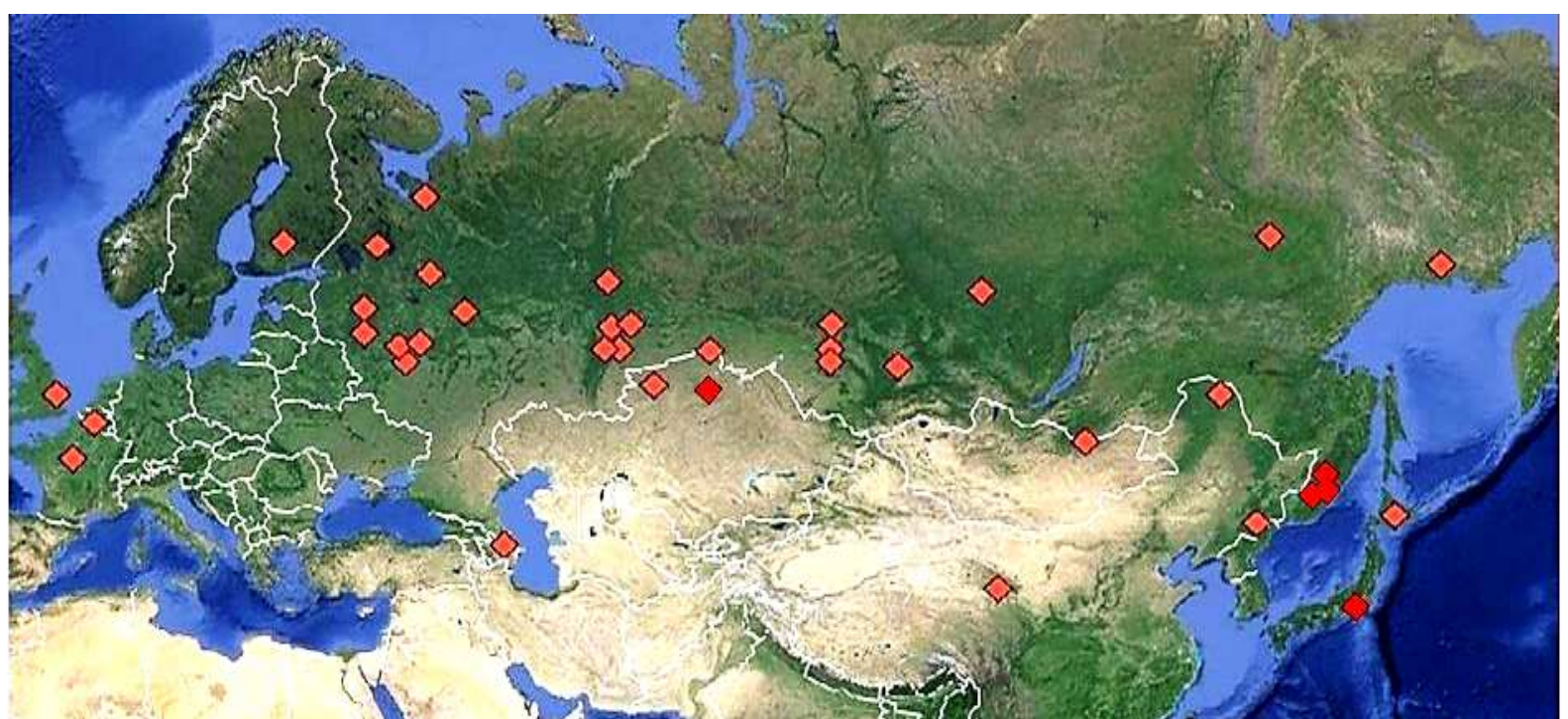

Fig. 1: The distribution of sample plots, on which biomass $(\mathrm{kg})$ of 1076 sample trees of Betula sp. is measured in different ecoregions of Eurasia.

Analysis of biomass of tree biomass is made on the basis of allometric additive models. According to the structure of disaggregating three-step additive model system [10,30], total biomass, estimated by the total equation, exploded into components according to the scheme presented in Fig. 2. The coefficients of the regression models for all three steps are evaluated simultaneously, which ensures additivity of the all components: total, intermediate and initial ones [10]. 


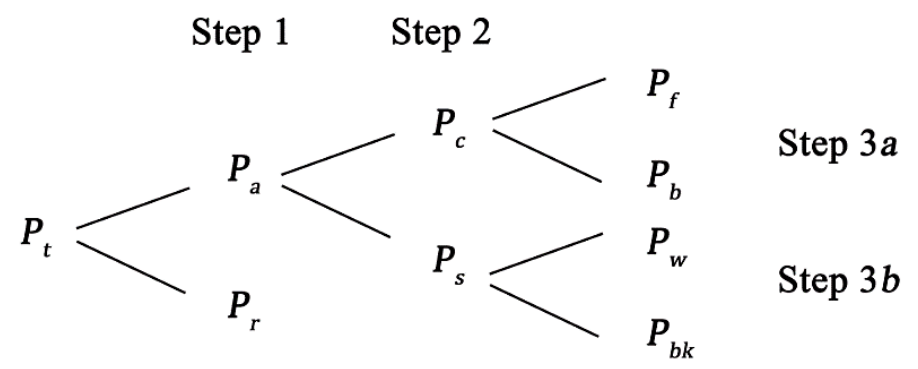

Fig. 2: The pattern of disaggregating three-step proportional weighting additive model.

Designation: $P_{t}, P_{r}, P_{a}, P_{c}, P_{s}, P_{f}, P_{b}, P_{w}$ and $P_{b k}$ are tree biomass respectively: total, underground (roots), aboveground, crown (needles and branches), stems above bark (wood and bark), needles, branches, stem wood and stem bark correspondingly, kg.

\section{Results and discussion}

Initial allometric models are calculated

$\ln P_{i}=a_{i}+b_{i}(\ln D)+c_{i}(\ln H)+d_{i}(\ln D)(\ln H)+\sum g_{i j} X_{j}$,

where $P_{i}$ - biomass of $i$-th component, $\mathrm{kg} ; D$ - diameter on breast height, $\mathrm{cm} ; H$ - tree height, $\mathrm{m}$; $i$-index of biomass component: total $(t)$, aboveground $(a)$, roots $(r)$, tree crown $(c)$, stem above bark $(s)$, foliage $(f)$, branches $(b)$, stem wood $(w)$ and stem bark $(b k) ; j$ - index (code) of dummy variable, from 0 to 10 (see Table 1). $\Sigma g_{i j} X_{j}$ - block of dummy variables for $i$-th biomass component of $j$-th ecoregion. Model (1) after antilogarithmic procedure has the form

$P_{i}=e^{a i} D^{b i} H^{c i} D^{d i(n H)} e^{\Sigma g i j X j}$.

Since calculation of regression coefficients in the model (1) is made in the transformed data, to eliminate biases caused by logarithmic modification of variables, in the equation the amendment proposed by [1] is introduced. Using the programme of common regression analysis the calculation of coefficients of equations (1) is performed and their characteristic is obtained, that is given in the Table 2 after correcting the logarithmic transformation by [1] and bringing it to the form (2). All the regression coefficients for numerical variables of the equations (2) are significant at the level of probability of 0.95 or higher, and the equations are adequate to empirical data.

By substituting the regression coefficients of initial equations from Table 2 into the structure of the additive model, presented in Table 3, when using three-step scheme of proportional weighting, we got transcontinental additive model of component composition of birch tree biomass of double harmonization, the final appearance of which is given in Table 4. The model is valid in the range of actual data of height and diameter of the sample trees shown in the Table 1.

By tabulating the model obtained (Table 4) according to the given values of $D$ and $H$ as well as by the values of the dummy variables, localizing the general model for eco-regions, you can calculate regional transcontinental standards for Eurasia, intended for estimating tree and forest additive biomass components. In particular, for the Ural region the similar regional standard is shown in the Table. 5. 


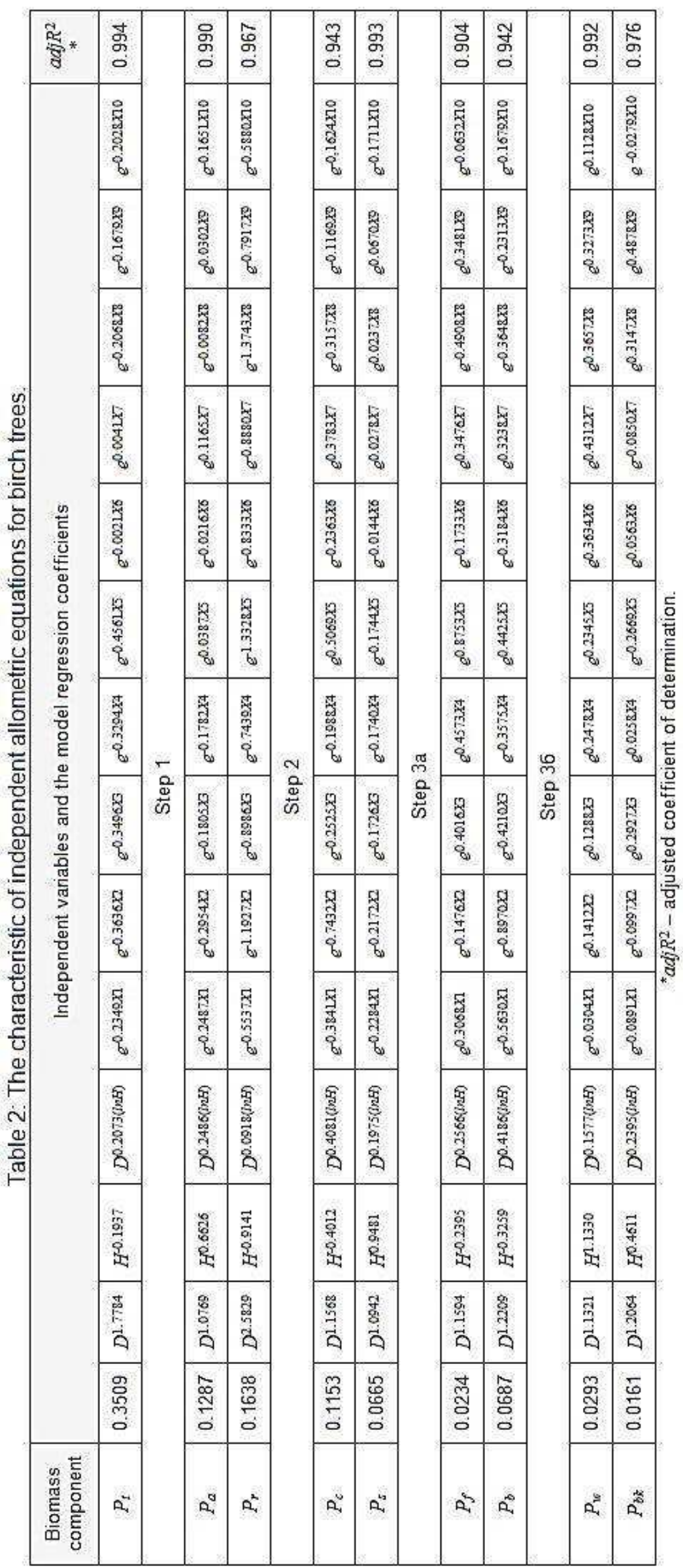


Table 3: The structure of three-step additive models obtained by proportional weighting. Symbols here and further see in equation (1).

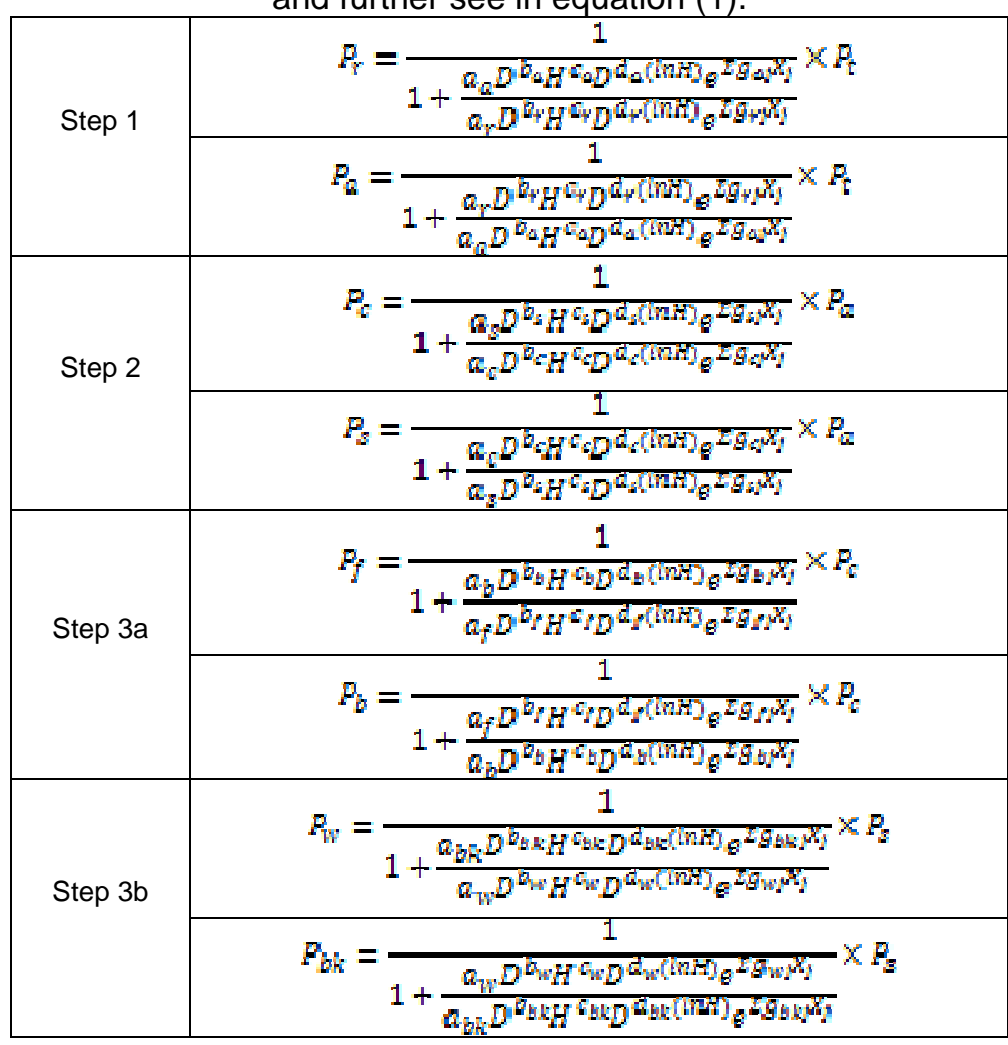

Table 4: Three-step additive model of component biomass composition for birch trees, obtained by proportional weighing.

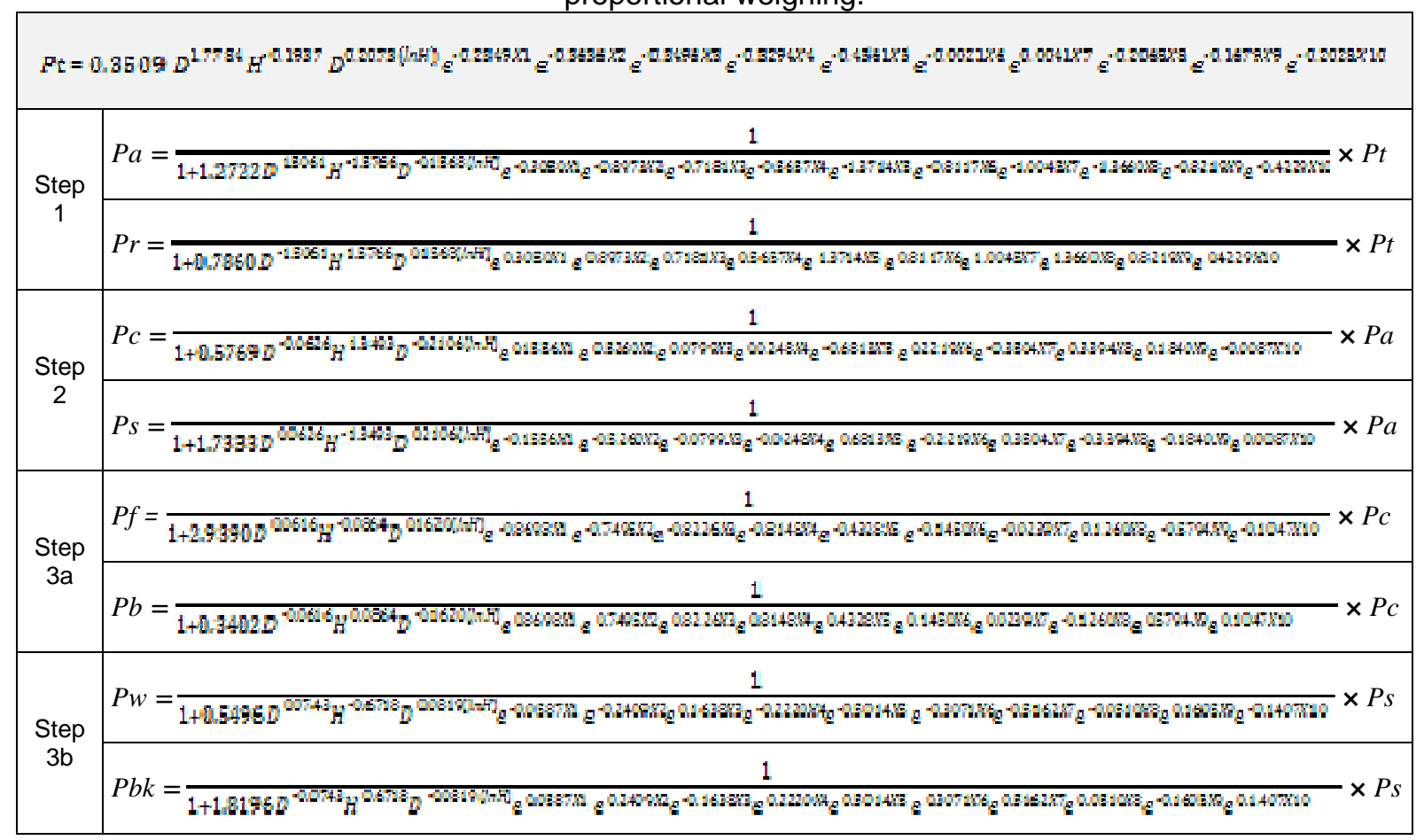


Table 5: Table for estimating the additive biomass of white birch trees on height and stem diameter in the Ural region.

\begin{tabular}{|c|c|c|c|c|c|c|c|c|}
\hline \multirow{2}{*}{$H, \mathrm{~m}$} & \multirow{2}{*}{ Biomass components } & \multicolumn{7}{|c|}{$\mathrm{DBH}, \mathrm{cm}$} \\
\hline & & 6 & 10 & 14 & 18 & 22 & 26 & 30 \\
\hline \multirow{9}{*}{6} & Total biomass & 8.12 & 24.35 & 50.20 & - & - & - & - \\
\hline & Roots & 1.76 & 8.29 & 22.00 & - & - & - & - \\
\hline & Aboveground & 6.36 & 16.06 & 28.20 & - & - & - & - \\
\hline & Tree crown & 1.06 & 3.23 & 6.37 & - & - & - & - \\
\hline & Foliage & 0.33 & 0.88 & 1.59 & - & - & - & - \\
\hline & Branches & 0.74 & 2.35 & 4.78 & - & - & - & - \\
\hline & Stem total & 5.30 & 12.83 & 21.84 & - & - & - & - \\
\hline & Stem wood & 4.44 & 10.56 & 17.72 & - & - & - & - \\
\hline & Stem bark & 0.86 & 2.28 & 4.11 & - & - & - & - \\
\hline \multirow{2}{*}{ H. $\mathrm{m}$} & \multirow{2}{*}{ Biomass components } & \multicolumn{7}{|c|}{ DBH. cm } \\
\hline & & 6 & 10 & 14 & 18 & 22 & 26 & 30 \\
\hline \multirow{9}{*}{10} & Total biomass & 8.89 & 28.15 & 60.13 & 106.00 & - & - & - \\
\hline & Roots & 0.86 & 4.53 & 13.23 & 28.98 & - & - & - \\
\hline & Aboveground & 8.03 & 23.62 & 46.90 & 77.03 & - & - & - \\
\hline & Tree crown & 0.88 & 3.29 & 7.63 & 14.05 & - & - & - \\
\hline & Foliage & 0.25 & 0.80 & 1.67 & 2.81 & - & - & - \\
\hline & Branches & 0.62 & 2.48 & 5.97 & 11.24 & - & - & - \\
\hline & Stem total & 7.16 & 20.33 & 39.27 & 62.98 & - & - & - \\
\hline & Stem wood & 6.24 & 17.40 & 33.17 & 52.63 & - & - & - \\
\hline & Stem bark & 0.92 & 2.93 & 6.10 & 10.34 & - & - & - \\
\hline \multirow{9}{*}{14} & Total biomass & 9.44 & 30.97 & 67.73 & 121.50 & 193.76 & - & - \\
\hline & Roots & 0.51 & 2.82 & 8.55 & 19.40 & 2.97 & - & - \\
\hline & Aboveground & 8.93 & 28.15 & 59.18 & 102.10 & 156.69 & - & - \\
\hline & Tree crown & 0.72 & 3.04 & 7.67 & 15.12 & 25.77 & - & - \\
\hline & Foliage & 0.20 & 0.69 & 1.53 & 2.73 & 4.29 & - & - \\
\hline & Branches & 0.53 & 2.35 & 6.14 & 12.40 & 21.49 & - & - \\
\hline & Stem total & 8.21 & 25.12 & 51.51 & 86.98 & 130.92 & - & - \\
\hline & Stem wood & 7.30 & 21.97 & 44.49 & 74.36 & 110.96 & - & - \\
\hline & Stem bark & 0.90 & 3.14 & 7.02 & 12.62 & 19.96 & - & - \\
\hline \multirow{9}{*}{18} & Total biomass & - & 33.26 & 74.02 & 134.54 & 216.81 & 322.54 & - \\
\hline & Roots & - & 1.93 & 5.96 & 13.78 & 2.47 & 46.39 & - \\
\hline & Aboveground & - & 31.33 & 68.06 & 120.76 & 190.03 & 276.14 & - \\
\hline & Tree crown & - & 2.78 & 7.40 & 15.23 & 26.94 & 43.07 & - \\
\hline & Foliage & - & 0.60 & 1.38 & 2.54 & 4.10 & 6.08 & - \\
\hline & Branches & - & 2.18 & 6.02 & 12.70 & 22.83 & 36.98 & - \\
\hline & Stem total & - & 28.55 & 60.66 & 105.53 & 163.09 & 233.08 & - \\
\hline & Stem wood & - & 25.34 & 53.18 & 91.59 & 140.36 & 199.11 & - \\
\hline & Stem bark & - & 3.21 & 7.48 & 13.94 & 22.73 & 33.97 & - \\
\hline \multirow{9}{*}{22} & Total biomass & - & - & 79.46 & 145.95 & 237.16 & 355.28 & 502.26 \\
\hline & Roots & - & - & 4.41 & 10.30 & 1.94 & 35.35 & 56.95 \\
\hline & Aboveground & - & - & 75.05 & 135.65 & 216.95 & 319.93 & 445.31 \\
\hline & Tree crown & - & - & 7.07 & 15.01 & 27.24 & 44.55 & 67.66 \\
\hline & Foliage & - & - & 1.24 & 2.35 & 3.87 & 5.83 & 8.25 \\
\hline & Branches & - & - & 5.83 & 12.67 & 23.37 & 38.72 & 59.40 \\
\hline & Stem total & - & - & 67.98 & 120.64 & 189.71 & 275.38 & 377.65 \\
\hline & Stem wood & - & - & 60.25 & 105.88 & 165.12 & 237.96 & 324.22 \\
\hline & Stem bark & - & - & 7.74 & 14.76 & 24.59 & 37.42 & 53.43 \\
\hline \multirow{9}{*}{26} & Total biomass & - & - & - & 156.18 & 255.56 & 385.06 & 547.07 \\
\hline & Roots & - & - & - & 8.01 & 1.52 & 27.85 & 45.13 \\
\hline & Aboveground & - & - & - & 148.17 & 239.73 & 357.21 & 501.94 \\
\hline & Tree crown & - & - & - & 14.68 & 27.16 & 45.18 & 69.67 \\
\hline & Foliage & - & - & - & 2.17 & 3.63 & 5.54 & 7.94 \\
\hline & Branches & - & - & - & 12.50 & 23.53 & 39.64 & 61.73 \\
\hline & Stem total & - & - & - & 133.49 & 212.57 & 312.03 & 432.27 \\
\hline & Stem wood & - & - & - & 118.17 & 186.66 & 272.05 & 374.48 \\
\hline & Stem bark & - & - & - & 15.32 & 25.91 & 39.98 & 57.79 \\
\hline
\end{tabular}


Because sometimes it is impossible to measure the height of trees in sample plots, for such cases when calculating the biomass per ha the auxiliary equation intended for using the proposed model (2) is calculated, adjusted to logarithmic transformation;

$H=1.9871 D^{0.8766} e^{0.2804 / D} e^{-0.0168 D} e^{0.0235 X 1} e^{-0.1800 X 2} e^{-0.0274 X 3} e^{0.0114 X 4} e^{-0.4268 X 5} e^{0.1510 X 6} e^{0.0188 X 7} \times$ $\times e^{-0.0439 X 8} e^{-0.1642 X 9} e^{-0.0024 X 10} ; \operatorname{adj} R^{2}=0.854$.

Variable $(1 / D)$ introduced in the structure of the model (3) for correction of allometry, biased in small trees due to the shift of diameter $D$ in the upper part of tree crown, and variable $(D)$ - for correction of allometry, suspended at large, old-aged trees. All the regression coefficients for numerical variables of the equation (3) are significant at the level of probability $P_{0.999}$, and the equation is adequate to empirical data.

Tabulating of built additive models (2) in Excel format is fulfilled. Because the volume of tables obtained can exceed the format of journal article, we are limit ourselves to some regional characteristics analysis of the structure of biomass of trees of the same size when using the fragment of summary table for birch (Table 6). Their analysis shows that the maximum values of total biomass of equal size trees occur in Western and Central Europe $(97 \mathrm{~kg})$ and in the eastern part of the birch areal - in Primorye, Northeast China, Japan $(80-98 \mathrm{~kg})$, that are under the influence of a humid climate of the Atlantic and Pacific oceans, accordingly. Lowest indices $(62-70 \mathrm{~kg})$ fall on UralSiberian region and the northern territory of the Far East (Magadan Oblast), characterized by a pronounced continental climate.

It was found $[8,24]$ that the correction of internal inconsistency of biomass equations by ensuring their additivity does not necessarily means improvements in the accuracy of biomass estimating, it is necessary to ascertain, whether adequate the additive model obtained and how its adequacy characteristics are related to the same indices of independent (trivial) equations?

To this purpose, the estimates of biomass obtained from independent and additive equations are compared with actual biomass values by calculating the coefficient of determination $R^{2}$ calculated by the formula

$R^{2}=1-\frac{E_{i=1}^{N}\left(Y_{i-1} P_{i}\right)^{2}}{E_{i=1}^{X}\left(Y_{i}-T_{i}\right)^{2}}$

where $Y_{i}$ - actual biomass values; $\hat{Y}_{i}$ - predicted biomass values; $\bar{Y}$ - the mean actual value of all $(N)$ trees.

To properly compare the adequacy of independent and additive equations, we reproduce the original data in a comparable condition, i.e. independent equations for all components of biomass are calculated according to the same data that the additive ones and the equations for the total biomass. Description of such "methodized" equations is given in the Table 7. The results of the comparison (Table 8) indicate that while additive equations internally consistent, but compared to the independent equations they have better characteristics of adequacy not for all component biomass. As already has been noted, when implementing the additivity principle, the aim of improving adequacy of the models obtained in comparison to the traditional models was not provided.

The ratio of actual values and derived ones by tabulating independent and additive tree biomass models (Fig. 3) shows the degree of correlativeness of the actual and calculated values and, in many cases, the absence of visible differences in the structure of residual variances obtained on two mentioned models. More or less the value of $R^{2}$ of one or the other model is determined by the random position of actual values of biomass of largest trees in confidence belt and uneven dispersion, namely accidental because of their small number and the greatest contribution to the residual variance (see Fig. 3). 

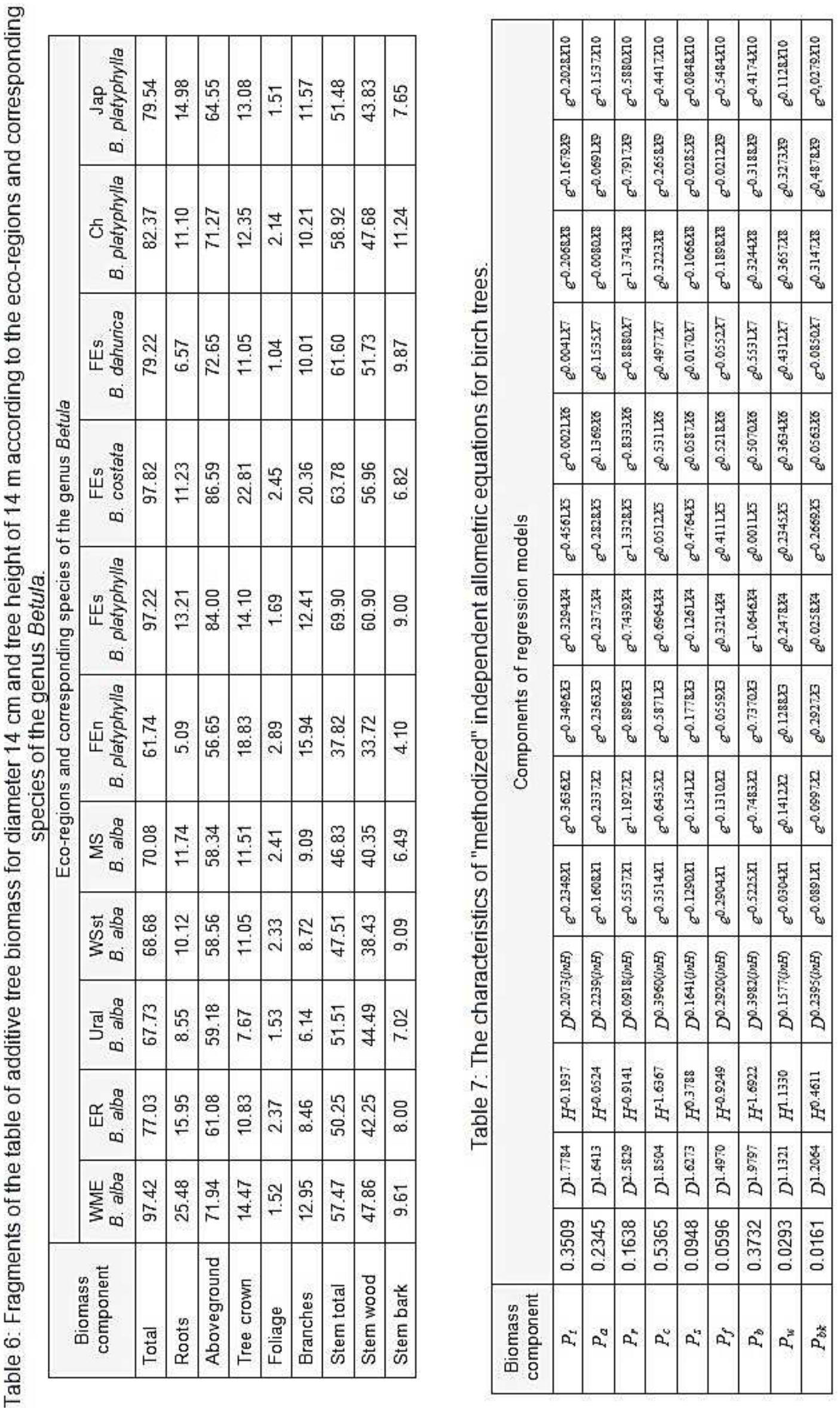
Table 8: Comparison of the adequacy indices of the independent and additive equations for birch tree biomass.

\begin{tabular}{|c|c|c|c|c|c|c|c|c|c|}
\hline \multirow{2}{*}{$\begin{array}{l}\text { Adequacy } \\
\text { index }\end{array}$} & \multicolumn{9}{|c|}{ Biomass components ${ }^{*}$} \\
\hline & $P t$ & $P a$ & $P r$ & Ps & $P w$ & $P b k$ & $P c$ & $\mathrm{~Pb}$ & $P f$ \\
\hline \multicolumn{10}{|c|}{ Independent equations } \\
\hline$R^{2}$ & 0.979 & 0.987 & 0.821 & 0.971 & 0.979 & 0.960 & 0.962 & 0.964 & 0.926 \\
\hline \multicolumn{10}{|c|}{ Additive equations } \\
\hline$R^{2}$ & 0.979 & 0.986 & 0.819 & 0.964 & 0.953 & 0.931 & 0.967 & 0.966 & 0.927 \\
\hline
\end{tabular}

* Designations see Fig. 2. Bold components, for which $R^{2}$ values of the additive models higher than independent ones.

\section{Conclusion}

Thus, thanks to formed by the authors the database on the biomass of 1076 sample trees of the genus Betula sp. growing on the territory of Eurasia, the trans-Eurasian model of tree biomass is proposed for the first time. The model takes into account regional differences in the biomass structure of equal-sized trees, harmonized on the principle of additivity. The proposed model and corresponding tables for estimating tree biomass makes them possible to calculate birch stand biomass (t/ha) on Eurasian forests when using measuring taxation.
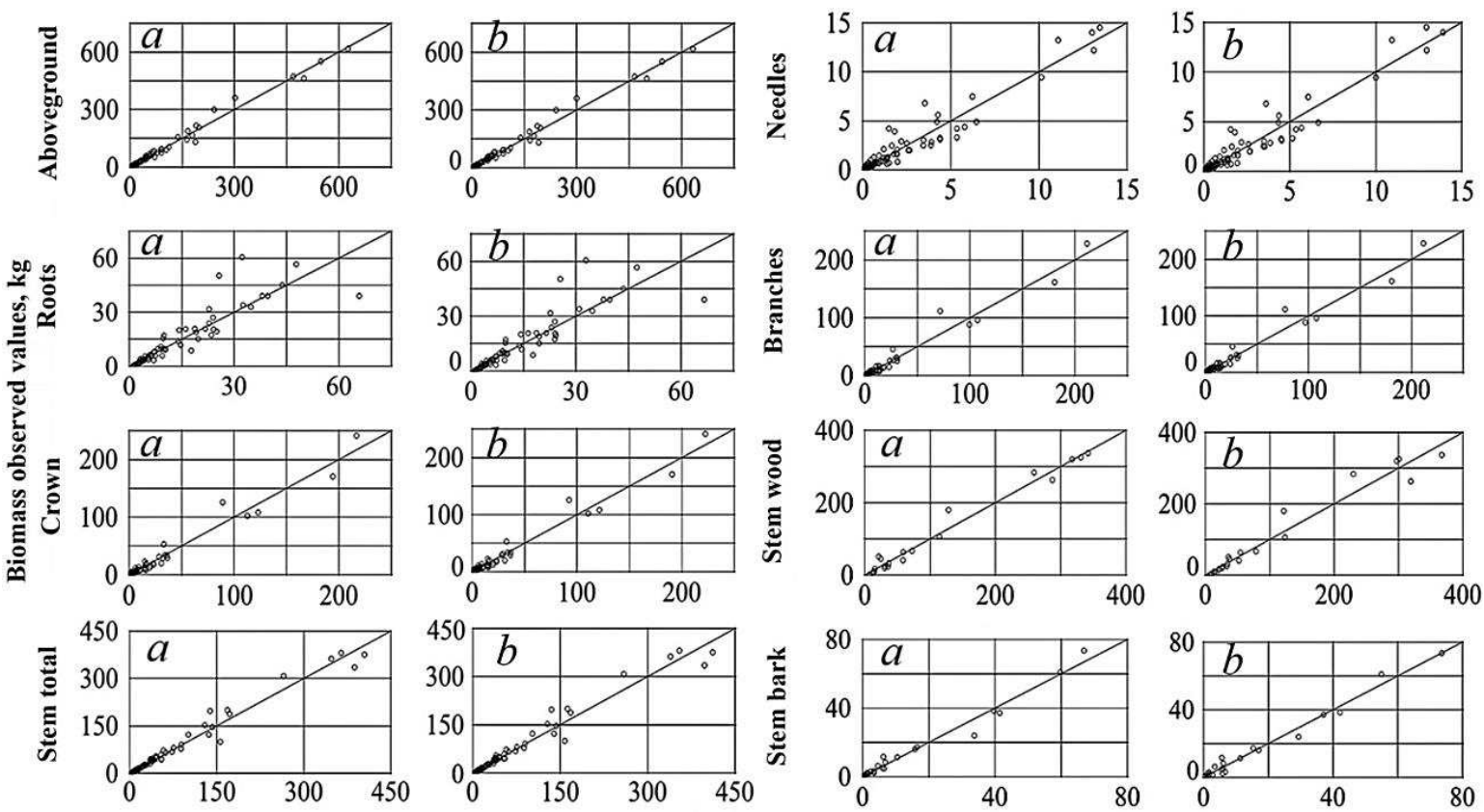

Fig. 3: The ratio of observed values and the values derived by calculation of independent $(a)$ and additive $(b)$ models of tree biomass.

\section{References}

[1] BASKERVILLE, G. L.: Use of logarithmic regression in the estimation of plant biomass. Canadian Journal of Forest Research, Vol. 2, 1972, pp. $49-53$.

[2] BI, H. - MURPHY, S. - VOLKOVA, L. - WESTON, CH. - FAIRMAN, T. - LI, Y. - LAW, R. NORRIS, J. - LEI X. - CACCAMO, G.: Additive biomass equations based on complete weighing of sample trees for open eucalypt forest species in south-eastern Australia. Forest Ecology and Management, Vol. 349, 2015, pp. 106 - 121, http://dx.doi.org/10.1016/j.foreco.2015.03.007.

[3] BI, H. - TURNER, J. - LAMBERT, M. J.: Additive biomass equations for native eucalypt forest trees of temperate Australia. Trees, Vol. 18, 2004, pp. 467 - 479.

[4] CARVALHO, J. P. - PARRESOL, B. R.: Additivity in tree biomass components of Pyrenean oak (Quercus pyrenaica Willd). Forest Ecology and Management, Vol. 179, 2003, pp. 269 - 276. 
[5] CASE, B. S. - HALL, R. J.: Assessing prediction errors of generalized tree biomass and volume equations for the boreal forest region of west-central Canada. Canadian Journal of Forest Research, Vol. 38, 2008, pp. 878 - 889.

[6] CROW, T. R.: Comparing biomass regressions by site and stand age for red maple. Canadian Journal of Forest Research, Vol. 13, 1983, pp. 283 - 288.

[7] CROWTHER, T. W. - GLICK, H. B. [...] - BRADFORD, M. A.: Mapping tree density at a global scale. Nature, Vol. 525, 2015, pp. 201 - 205, DOI: 10.1038/nature14967.

[8] CUNIA, T. - BRIGGS, R. D.: Forcing additivity of biomass tables: some empirical results. Canadian Journal of Forest Research, Vol. 14, 1984, pp. 376 - 384.

[9] DARYAEI, A. - SOHRABI, H.: Additive biomass equations for small diameter trees of temperate mixed deciduous forests. Scandinavian Journal of Forest Research, Vol. 31, No. 4, 2015, pp. 394 398.

[10] DONG, L. - ZHANG, L. - LI, F.: A three-step proportional weighting system of nonlinear biomass equations. Forest Science, Vol. 61, No. 1, 2015b, pp. 35 - 45.

[11] DONG, L. - ZHANG, L. - LI, F.: Developing additive systems of biomass equations for nine hardwood species in Northeast China. Trees, Vol. 29, No. 4, 2015a, pp. 1149 - 1163, https://doi. org/10.1007/s00468-015-1196-1.

[12] DONG, L. - ZHANG, L. - LI, F.: Developing two additive biomass equations for three coniferous plantation species in Northeast China. Forests, Vol. 7, No. 7, 2016, pp. 130 - 136, DOI: 10. 3390/f7070136.

[13] FEHRMANN, L. - LEHTONEN, A. - KLEINN, C. - TOMPPO, R.: Comparison of linear and mixed-effect regression models and a k-nearest neighbour approach for estimation of single tree biomass. Canadian Journal of Forest Research, Vol. 38, 2008, pp. 1 - 9.

[14] FU, L. - SHARMA, R. P. - HAO, K. - TANG, S.: A generalized interregional nonlinear mixedeffects crown width model for Prince Rupprecht larch in northern China. Forest Ecology and Management, Vol. 389, 2017, pp. 364 - 373.

[15] FU, L. - SUN, H. - SHARMA, R. P. - LEI, Y. - ZHANG, H. - TANG, S.: Nonlinear mixed-effects crown width models for individual trees of Chinese fir (Cunninghamia lanceolata) in south-central China. Forest Ecology and Management, Vol. 302, 2013, pp. 210 - 220.

[16] FU, L. Y. - ZENG, W. S. - TANG, S. Z. - SHARMA, R. P. - LI, H. K.: Using linear mixed model and dummy variable model approaches to construct compatible single-tree biomass equations at different scales - A case study for Masson pine in Southern China. Journal of Forest Science, Vol. 58, No. 3, 2012, pp. $101-115$.

[17] JACOBS, M. W. - CUNIA, T.: Use of dummy variables to harmonize tree biomass tables. Canadian Journal of Forest Research, Vol. 10, No. 4, 1980, pp. 483 - 490.

[18] LI, C. M. - ZHANG, H. R.: Modelling dominant height for Chinese fir plantation using a non-linear mixed-effects modelling approach. Scientia Silvae Sinicae, Vol. 46, 2010, pp. 89 - 95.

[19] LI, L. X. - HAO, Y. H. - ZHANG, Y.: The application of dummy variable in statistical analysis. The Journal of Mathematical Medicine, Vol. 19, 2006, pp. 51 - 52.

[20] LIANG, J. - CROWTHER, T. W. - [...] - REICH, P. B.: Positive biodiversity-productivity relationship predominant in global forests. Science, Vol. 354, No. 6309, 2016, pp. 196 - 208, DOI: 10.1126/science.aaf8957.

[21] PARRESOL, B. R.: Additivity of nonlinear biomass equations. Canadian Journal of Forest Research, Vol. 31, No. 5, 2001, pp. 865 - 878, https://doi.org/10.1139/x00-202.

[22] PASTOR, J. - ABER, J. - MELILLO, J.: Biomass prediction using generalized allometric regressions for some northeast tree species. Forest Ecology and Management, Vol. 7, 1984, pp. 265 - 274, DOI: 10.1016/0378-1127(84)90003-3.

[23] POORTER, H. - JAGODZINSKI, A. M. - RUIZ-PEINADO, R. - KUYAH, S. - LUO, Y. OLEKSYN, J. - USOLTSEV, V. A. - BUCKLEY, T. N. - REICH, P. B. - SACK, L.: How does biomass allocation change with size and differ among species? An analysis for 1200 plant species from five continents. New Phytologist, Vol. 208, No 3, 2015, pp. 736 - 749, DOI:10.1111/nph.13571.

[24] REED, D. D. - GREEN, E. J.: A method of forcing additivity of biomass tables when using nonlinear models. Canadian Journal of Forest Research, Vol. 15, 1985, pp. 1184 - 1187.

[25] RUTISHAUSER, E. - NOOR'AN, F. - LAUMONIER, Y. - HALPERIN, J. - RUFI'IE HERGOUALCH, K. - VERCHOT, L.: Generic allometric models including height best estimate forest biomass and carbon stocks in Indonesia. Forest Ecology and Management, Vol, 307, 2013, pp. $219-225$.

[26] SCHENK, H. J. - JACKSON, R. B.: The global biogeography of roots. Ecological Monographs, Vol. 72, No. 3, 2002, pp. 311 - 328. 
[27] SCHMITT, M. D. C. - GRIGAL, D. F.: Generalized biomass estimation equations for Betula papyrifera Marsh. Canadian Journal of Forest Research, Vol. 11, 1981, pp. 837 - 840.

[28] STANKOVA, T. - GYULEVA, V. - TSVETKOV, I. - POPOV, E. - VELINOVA, K. VELIZAROVA, E. - DIMITROV, D. N. - HRISTOVA, H. - KALMUKOV, K. - DIMITROVA, P. GLUSHKOVA, M. - ANDONOVA, E. - GEORGIEV, G. P. - KALAYDZHIEV, I. - TSAKOV, H.: Aboveground dendromass allometry of hybrid black poplars for energy crops. Annals of Forest Research, Vol. 59, No. 1, 2016, pp. 61 - 74.

[29] STAS, S. M. - RUTISHAUSER, E. - CHAVE, J. - ANTEN, N. P. R. - LAUMONIER, Y.: Estimating the aboveground biomass in an old secondary forest on limestone in the Moluccas, Indonesia: Comparing locally developed versus existing allometric models. Forest Ecology and Management, Vol. 389, 2017, pp. 27 - 34.

[30] TANG, S. - ZHANG, H. - XU, H.: Study on establish and estimate method of compatible biomass model. Scientia Silvae Sinica, Vol. 36, 2000, pp. 19 - 27 (in Chinese with English abstract).

[31] TANG, S. Z. - LANG, K. J. - LI, H. K.: Statistics and Computation of Biomathematical Models (ForStat Course). Beijing, Science Press, 2008, pp. 115 - 261.

[32] TRITTON, L. M. - HORNBECK, J. W.: Biomass estimation for northeastern forests. Bulletin of the Ecological Society of America, Vol. 62, 1981, pp. 106 - 107.

[33] USOLTSEV, V. A.: Compiling forest biomass data banks. Yekaterinburg, Ural Branch of RAS, 1998, p. 541, http://elar.usfeu.ru/handle/123456789/3224.

[34] USOLTSEV, V. A.: Single-tree biomass of forest-forming species in Eurasia: database, climaterelated geography, weight tables. Yekaterinburg: Ural State Forest Engineering University, 2016a, 336 p., http://elar.usfeu.ru/handle/123456789/5696.

[35] USOLTSEV, V. A.: Single-tree biomass data for remote sensing and ground measuring of Eurasian forests. Yekaterinburg: Ural State Forest Engineering University, 2016b, http://elar.usfeu.ru/handle/123456789/6103, (CD-version in English and Russian).

[36] USOLTSEV, V. A.: On additive models of tree biomass: some uncertainties and the attempt of their analytical review. Ėko-potencial, Vol. 2, No. 18, 2017, pp. 23 - 46, http://elar.usfeu.ru/handle/ $123456789 / 6550$.

[37] USOLTSEV, V. A. - KOLTUNOVA, A. I. - KAJIMOTO, T. - OSAWA, A. - KOIKE, T.: Geographical gradients of annual biomass production from larch forests in Northern Eurasia. Eurasian Journal of Forest Research, Vol. 5, 2002, pp. 55 - 62.

[38] VIEILLEDENT, G. - VAUDRY, R. - ANDRIAMANOHISOA, S. F. D. - RAKOTONARIVO, O. S. RANDRIANASOLO, Z. H. - RAZAFINDRABE, H. N. - BIDAUD RAKOTOARIVONY, C. EBELING, J. - RASAMOELINA, M.: A universal approach to estimate biomass and carbon stock in tropical forests using generic allometric models. Ecological Applications, Vol. 22, No. 2, 2012, pp. 572 - 583.

[39] WANG, M. - BORDERS, B. E. - ZHAO, D.: An empirical comparison of two subject-specific approaches to dominant heights modelling: The dummy variable method and the mixed model method. Forest Ecology and Management, Vol. 255, 2008, pp. 2659 - 2669.

[40] ZENG, W. S.: Using nonlinear mixed model and dummy variable model approaches to construct origin-based single tree biomass equations. Trees, Vol. 29, No. 1, 2015, pp. 275 - 283.

[41] ZENG, W. S. - TANG, S. Z. - XIA, Z. S. - ZHU, S. - LUO, H. Z.: Using linear mixed model and dummy variable model approaches to construct generalized single-tree biomass equations in Guizhou. Forest Research, Vol. 24, No. 3, 2011, pp. 285 - 291.

[42] ZIANIS, D. - MENCUCCINI, M.: Aboveground biomass relationships for beech (Fagus moesiaca $\mathrm{Cz}$.) trees in Vermio Mountain, Northern Greece, and generalized equations for Fagus sp. Annals of Forest Science, Vol. 60, 2003, pp. 439 - 448, DOI:10.1051/forest:2003036. 